\title{
Soil Quality of Kapatagan Watershed, Lanao del Norte
}

\author{
Victoria E. Matunog, Al Jether P. Yap, Hannah E. Gonzaga, \\ Jendelou H. Buhi-an \\ Natural Science Department, College of Arts and Sciences, Misamis University, \\ Ozamiz City, Philippines \\ Corresponding email: victoria_elcano@yahoo.com.ph
}

\begin{abstract}
Kapatagan watershed had once provided abounding natural resources to the community but is now degraded due to natural and anthropogenic activities. A rapid site assessment was conducted to determine soil quality of Kapatagan watershed. Seven representative barangays were selected as sampling sites. Moisture, texture, drainage, color and slope, $\mathrm{pH}$, potassium, nitrogen and phosphorus content were the physicochemical properties of soil assessed. Results showed that most of these physicochemical qualities were within the standards while some were already at the borderline and few were outside the standard limit. Soil quality in Curvada was still good and suitable for plant growth. Phosphorus in soil of Mahayahay, Bel-is and Cathedral was already depleted. Mahayahay soil was slightly degraded as indicated further by the color and the surface $\mathrm{pH}$ value. These results can be used to evaluate past practices to determine their impact to watershed soil quality and to formulate policy direction towards sustainability. However, further investigation on various chemical, physical, and biological properties is necessary to comprehensively evaluate the current status on soil quality of the area.
\end{abstract}

Keywords: anthropogenic, natural resources, physicochemical properties, rapid site assessment, sustainability 


\section{Introduction}

Watershed is an area of land where all of the water that falls in it ends up in the same place (Environmental Fact Sheet, 2006) known as drainage basin such as stream, lake, estuary, wetland, aquifer or other water basin (Department of Environmental Protection, 2013). It is a natural capital which sustains life and contributes significantly to the wealth and welfare of human societies (Wolflin et al., 2008). Air, water, soil, flora and fauna constituted this natural capital and the ecosystem services resulting from them (United Nations 'Rio+20' Earth Summit, 2012). These resources and the people within the watershed are all connected in a delicate balance (Natural Resources Conservation Center, 2013). Whenever soil, water, and the production systems in the rainfed agroecosystem are in harmony with the environment, sustainability of the production system can be achieved (Sahrawat et al., 2010). These require understanding of the watershed, and the system it resides and other factors that will affect its condition.

Soil is a complex component in watershed natural resources. It supports growth of food crops to feed the people. However, natural processes and anthropogenic activities alter soil quality through multifaceted phenomenon. Natural processes, which affect soil quality, include floods, bushfires or drought, while human activities include overgrazing, deforestation, and poor agricultural practices. The severe land degradation is attributed to the heavy concentration of the population in the highlands, coupled with unchanged agricultural technology, thus putting tremendous stress on the watershed natural resources, particularly soil fertility (Kumasi \& Asenso-Okyere, 2011). The prevention of soil degradation and the preservation of soil quality at a desirable level are complex issues involving climatic, soil, plant, and social factors and their interactions (Mandal et al., 2011).

Soil quality is defined as the fitness of soil for soil use. At the agricultural standpoint, a high quality soil sustained productive growth of crops with minimal impact on the wider environment (Beare, 1997). This requires monitoring changes and determining trends, through indicators of soil quality in different agroecological zones which vary according to societal goals (Arshad \& Martin, 2002). However, complexity of soil biological behaviors made the selection of soil quality indicators a potentially onerous task (Merrington, 2006). 
Consequently, characterization of soil quality had focused primarily on physical and chemical properties due to availability of simple and standard methods.

Kapatagan watershed is found in the province of Lanao del Norte and is a part of Maranding watershed in addition to Lala, Salvador, Magsaysay, Sapad, Nunungan, Sultan Naga Dimaporo and Tangkal. It comprises the Kapatagan valley which is considered as the rice granary of the province, blessed with abundant water sources (Natural Resources, 2013). The Municipality of Kapatagan has a total land area of 25,048.41 hectares per certification issued by the Bureau of Land Management Services (LMS) of the Department of Environment and Natural Resources (DENR), Region XII dated September 7, 1998 (About Us Kapatagan, 2009). The land area is apportioned into agriculture $56.91 \%$, open grassland/denuded forest $21 \%$, aquaculture (crabs, shrimps and freshwater fishes) $15.83 \%$ and the remaining $6.26 \%$ for other amenities. Catchments in the area drain into five large river systems, Maranding, Panoloon, Butadon, Kidalos and Balili which empty into the Panguil Bay through Lapinig outlet (About Us Kapatagan, 2009). Rice industry in the area chiefly utilizes the Maranding River through National Irrigation Authority for water supply.

However, natural and anthropogenic activities degraded Kapatagan watershed resources. River overflow, especially during rainy seasons, caused floods resulting to destruction and even death to farm and land animals (About Us Kapatagan, 2009). It is one of the 12 major watersheds critical to the effort to boost food production in Mindanao which is now less productive since they have been overly exploited and misused (Manual, 2011). This condition prompted the LGU Kapatagan, Lanao del Norte to conduct rapid site assessment in the area to establish baseline information prior to the formulation of intensive rehabilitation for sustainable environmental management. The action aligned with Republic Act 7160 section 447, otherwise known as the Local Government Code of 1991, whereby LGUKapatagan is empowered to protect the environment and impose appropriate penalties for acts which endanger the environment (Republic Act 7161, 1991). In the pursuit of environmental goal, this study aimed to determine soil quality to contribute in delineating the current condition of Kapatagan watershed. The result of the study can 
be used to evaluate past practices to determine their impact on the watershed soil quality in the area and formulate policy direction towards sustainability.

\section{Materials and Methods}

The study was conducted at Kapatagan, Lanao del Norte from the month of April to June 2013. Seven sampling areas were identified, namely: Malinas for cave; Mahayahay for upland agriculture; Bel-is for forest; Cathedral for riverine; Curvada for agriculture; Lapinig for residential area; and San Vicente for mixed agricultural area. The sampling areas were characterized with five physical properties such as moisture, texture, drainage, color and slope; and four chemical properties such as $\mathrm{pH}$, potassium content, nitrogen and phosphorus.

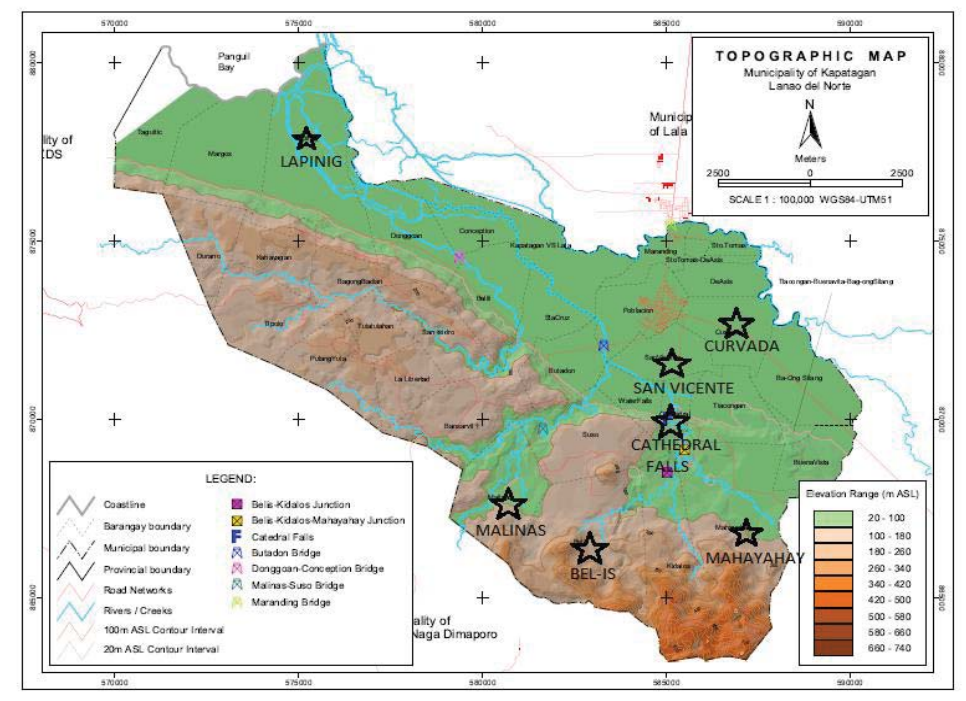

$\star$ - representative study areas

Figure 1. Location map showing the sampling areas in Kapatagan, Lanao del Norte

Soil $\mathrm{pH}$ and moisture tester determined soil surface $\mathrm{pH}$ and moisture. To measure the $\mathrm{pH}$ value, the metallic electrode was inserted into the soil completely, while positioning the electrode as near crop 
root as possible. The white button of the tester was un-depressed and after one minute, the value at the corresponding $\mathrm{pH}$ scale was read. Similar procedure was done in determining the moisture, except that the white button was depressed and separate scale for moisture, ranging from 1 (dry) to 8 (wet), was read.

Soil composite sample was used in determining soil texture, macronutrients and composite $\mathrm{pH}$. Composite soil sampling of Self and Soltanpour (2010) with few modifications was used in this study. Soil sampling was done using 10-inch Galvanized Steel Soil Sampler. Ten to fifteen cores, $0-8$ inches depth excluding the surface litter, were collected in a zigzag pattern over identified sampling areas. The soil samples were air dried and sieved to $<2.0 \mathrm{~mm}$. About 1 pint of the soil sample was placed in a plastic bag for analysis.

The hydrometer method by Spriggs and Ray-Maitra (2007) and Kenkel (2003) were combined and used in this study. The method determined the soil texture using $0.2 \mathrm{M} \mathrm{Na}_{3} \mathrm{PO}_{4}$ dispersing solution (Wintermyer \& Kinter, 2004) instead of the commonly used sodium metaphosphate; a 1000-mL graduated cylinder and a hydrometer calibrated at $20^{\circ} \mathrm{C}$. Specific gravity and temperature readings were obtained within the first two minutes and at the end of 24 hours. The data gathered for the first two minutes were used to calculate silt and clay in the suspension. The 24-hour data were used to calculate clay alone. The amount of sand in soil was calculated by subtracting the amount of silt and clay (two-minute reading) from the total amount of soil subjected into the test. The amount of silt was determined by subtracting the amount of clay (24-hour reading) from the calculated silt and clay (two-minute reading). Weights were used to calculate $\%$ sand, \%silt and \%clay which were subsequently used to determine soil class texture with the aid of soil texture triangle (Ritter, 2006).

The ability of soil to drain water was determined using the percolation rate. This test assumed that soil is already saturated with water as heavy rainfall frequently hit the area during the sampling period. Two feet deep holes were dug and filled with water. The initial height of water was measured. At the end of $30 \mathrm{~min}$, the final height of water was determined. The data were used to calculate the percolation rate. The ability of soil to drain water is categorized into poor (water drains less than $1 \mathrm{inch} / \mathrm{hr}$ ), well drain (water drains 1-6 inches/hr) and excessive (water drains more than 6 inches/hr) (Department of 
Horticulture, 2013). Prior to the addition of water, the mottling characteristics of the soil were examined. The slopes of the sampling area were determined through ocular examination.

Soil Test Kit (STK) was used to determine the soil macronutrients. Previously air dried and sieved composite soil was used to measure nitrogen, phosphorus and potassium as well as composite soil $\mathrm{pH}$ value.

\section{Results and Discussion}

Table 1 shows the five physical properties of the seven sampling areas. Among the seven sampling areas, Malinas had the highest water content, with soil moisture of 7.6. The heavy rain and presence of canopy trees may have attributed to the wet soil in Malinas despite the higher sand proportion it contained which could have lessened the capacity to hold water (Ball, 2001). In the populated area of Lapinig, where soil was mostly covered with grass, moisture content was lesser than in Malinas. Hot and dry climate, bare surface and exposure to sunlight are factors that promote soil evaporation in the two areas (Lannan, 2009). Conversely, mottling with red and gray colors in Lapinig signified waterlogged. This result suggests that the area is already at a very low elevation whereby water saturates the soil from time to time. Furthermore, the area is very close to a pond and a river where water rises during high tide. Drainage and soil color determination in Malinas were cancelled due to some constraints in digging which were required for these two tests. Bel-is also possessed sandy loam soil and exhibited excessive drainage, which was supported by the homogeneous brown color of the soil. However, the high moisture content (5.2) was attributed to heavy vegetation (Wang, 2013a) and distance from the water stream (Kostka, 1994) because the sampling area was heavily canopied with big trees and very close to waterfalls. The ability to drain water in Mahayahay ricefield with silty loam soil was poor. Silty loam soil is finer than sandy loam and when compacted prevents water from draining (Ball, 2001). The soil in this area was highly mottled with gray color which signified poor aeration where iron existed in reduced form. A rice paddy with silty loam soil and flat slope promoted saturation with water in the area. Cathedral, Curvada and San Vicente possess loam soil, the best soil quality, with 
soil moisture ranging from 4.5 to 5.8 . Loamy soil which consisted of evenly mixed sand, clay and silt, consequently drained well. The black color soil in Curvada indicated the presence of organic matter while brown and red colors signified good aeration where iron existed in oxidized form.

Table 1. Physical properties of soil at Kapatagan, Lanao del Norte.

\begin{tabular}{|c|c|c|c|c|c|c|c|c|}
\hline \multirow[b]{2}{*}{ Area } & \multirow[b]{2}{*}{ Moisture } & \multicolumn{4}{|c|}{ Texture } & \multirow[b]{2}{*}{ Drainage } & \multirow[b]{2}{*}{ Color } & \multirow[b]{2}{*}{ Slope } \\
\hline & & $\begin{array}{c}\% \\
\text { Sand }\end{array}$ & $\begin{array}{c}\% \\
\text { Clay }\end{array}$ & $\begin{array}{l}\% \% \\
\text { Silt }\end{array}$ & $\begin{array}{c}\text { Texture } \\
\text { class }\end{array}$ & & & \\
\hline $\begin{array}{l}\text { Malinas } \\
\text { (cave) }\end{array}$ & 7.6 & 62.5 & 11.1 & 26.4 & sandy loam & NA & NA & steep \\
\hline $\begin{array}{l}\text { Bel-is } \\
\text { (forest) }\end{array}$ & 5.2 & 59.3 & 14.2 & 26.6 & sandy loam & excessive & $\begin{array}{l}\text { homogeneous } \\
\text { brown }\end{array}$ & steep \\
\hline $\begin{array}{l}\text { Mahayahay } \\
\text { (ricefield- } \\
\text { upland) }\end{array}$ & 6.2 & 24.6 & 18.0 & 57.4 & silt loam & poor & $\begin{array}{l}\text { highly mottled } \\
\text { with gray } \\
\text { brown, reddish, } \\
\text { yellow }\end{array}$ & flat \\
\hline $\begin{array}{l}\text { Cathedral } \\
\text { (riverine) }\end{array}$ & 4.5 & 30.9 & 21.1 & 48.0 & loam & well drain & $\begin{array}{l}\text { mottled with } \\
\text { brown, } \\
\text { dark brown }\end{array}$ & $\begin{array}{l}\text { gently } \\
\text { rolling }\end{array}$ \\
\hline $\begin{array}{l}\text { Curvada } \\
\text { (agricultural- } \\
\text { ricefield) }\end{array}$ & 5.5 & 40.2 & 24.3 & 35.5 & loam & well drain & $\begin{array}{l}\text { mottled with } \\
\text { black, } \\
\text { brown, red }\end{array}$ & flat \\
\hline $\begin{array}{l}\text { San Vicente } \\
\text { (agricultural- } \\
\text { mixed) }\end{array}$ & 5.8 & 45.6 & 14.7 & 39.8 & loam & well drain & $\begin{array}{l}\text { homogeneous } \\
\text { brown }\end{array}$ & flat \\
\hline $\begin{array}{l}\text { Lapinig } \\
\text { (residential } \\
\text { area) }\end{array}$ & 6.0 & 54.2 & 14.8 & 31.0 & sandy loam & excessive & $\begin{array}{l}\text { mottled with } \\
\text { reddish, } \\
\text { gray }\end{array}$ & $\begin{array}{l}\text { gently } \\
\text { rolling }\end{array}$ \\
\hline
\end{tabular}

NA - not applicable

The chemical properties determined in this study were the $\mathrm{pH}$ and the macronutrients which included potassium, nitrogen and phosphorus (Table 2). Two $\mathrm{pH}$ values were measured, the surface using the soil $\mathrm{pH}$ and moisture tester, and the composite using STK. Surface soils in all areas were acidic with $\mathrm{pH}$ values lower than the composite soil samples. Factors affecting the acidity of the surface soil include heavy rainfall, which causes leaching of nutrients; removal of alkaline products and other minerals from the farming system; adding nitrogen based fertilizers and the accumulation of organic matter (Roosebelt, 2011). Mahayahay had the lowest surface $\mathrm{pH}$ value due to the abundance of animal manure from the tethered carabaos in the area. The surface soil at one to two inch-depth acidifies faster than the 
soil below it (Anderson et al., 2010). Consequently, the composite soil sample, which included soil up to eight inches deep, had higher $\mathrm{pH}$ value than the surface $\mathrm{pH}$. The optimum $\mathrm{pH}$ for most plants is 5.5 to 7.0. At this value, bacteria which release nitrogen from organic matter and fertilizers, operate best and abundantly provide nutrients to the plant. At $\mathrm{pH}$ below 5, aluminum in soil may become more toxic to plants. At extremely basic or acidic condition, clayey soil tends to become sticky and hard to cultivate (Perry, 2003). Soil pH in Lapinig was slightly basic which may be attributed to the household wastes in the area.

Table 2. Chemical properties of the soil in Kapatagan, Lanao del Norte.

\begin{tabular}{|c|c|c|c|c|c|}
\hline \multirow[b]{2}{*}{ Area } & \multicolumn{2}{|c|}{$\mathrm{pH}$} & \multicolumn{3}{|c|}{ Nutrients } \\
\hline & surface & composite & potassium & nitrogen & phosphorus \\
\hline Malinas (cave) & 6.5 & 6.8 & $\begin{array}{c}\text { very } \\
\text { sufficient }\end{array}$ & low & low \\
\hline Bel-is (forest) & 5.5 & 5.8 & $\begin{array}{l}\text { moderately } \\
\text { sufficient }\end{array}$ & low & none \\
\hline $\begin{array}{l}\text { Mahayahay } \\
\text { (ricefield-upland) }\end{array}$ & 2.0 & 6.4 & sufficient & medium & none \\
\hline Cathedral (riverine) & 5.3 & 5.8 & $\begin{array}{c}\text { very } \\
\text { sufficient }\end{array}$ & low & none \\
\hline $\begin{array}{l}\text { Curvada } \\
\text { (agricultural- } \\
\text { ricefield) }\end{array}$ & 5.0 & 5.8 & $\begin{array}{c}\text { very } \\
\text { sufficient }\end{array}$ & low & high \\
\hline $\begin{array}{l}\text { San Vicente } \\
\text { (agricultural-mixed) }\end{array}$ & 4.8 & 5.8 & sufficient & low & high \\
\hline $\begin{array}{l}\text { Lapinig } \\
\text { (residential area) }\end{array}$ & 5.5 & 7.2 & $\begin{array}{l}\text { moderately } \\
\text { sufficient }\end{array}$ & low & high \\
\hline
\end{tabular}

Plants use soil nutrients to grow and reproduce. Potassium is an essential nutrient that affects most of the biochemical and physiological processes that influence plant growth and metabolism. It also contributes to the survival of plants exposed to various biotic and abiotic stresses (Wang et al., 2013b). Nitrogen and phosphorus are both part of biomolecules in plants but are the most limited in natural conditions. Nitrate is the most common form of nitrogen but is easily leached and denitrified; while orthophosphate for phosphorus, has low mobility and readily reacts with $\mathrm{Ca}^{+2}, \mathrm{Mg}^{+2}$ and $\mathrm{Al}^{+3}$, forming precipitates (Costa et al., 2011). 
All representative areas contained adequate concentration of potassium to support plant growth but varied nitrogen and phosphorus content. Curvada, San Vicente and Lapinig soils had enough phosphorus reserves but with low nitrogen content. These areas required nitrogen supplementation to support plant growth. Malinas had low nitrogen and phosphorus, thereby required supplementation of these two nutrients if utilized for crop production. Mahayahay had medium level of nitrogen and depleted phosphorus. Phosphorus supplement promotes plant productivity in the area. Bel-is and Cathedral had low nitrogen and depleted phosphorus. These areas require minimum supplementation of nitrogen and totally depend on phosphorus fertilizer for plants to be productive. However, application of nitrogen-based fertilizers requires moderation, because it lowers the $\mathrm{pH}$ value and makes the soil more acidic (Siavoshi et al., 2010)

\section{Conclusion and Recommendations}

Soil in Kapatagan watershed showed varied qualities with respect to physical properties: moisture, soil texture class; drainage; mottling and slope; and chemical properties: $\mathrm{pH}$ and potassium, nitrogen phosphorus content. Most of these qualities are still within the standards while some are already at the borderline and few are outside the standard limit. Despite the pressing need to address these issues, further investigation on soil quality is still necessary to evaluate current status of various chemical, physical, and biological properties. These properties interact in complex ways to promote land productivity. Conservation, remediation or mitigation requires comprehensive assessment of the previous practices, research on sustainable management and modelling/piloting technologies to reestablish the wellness of the soil, each ecosystem and the community as a whole. 


\section{Acknowledgment}

This study is inspired by Misamis University and Local Government of Kapatagan, Lanao del Norte which joined force to commence this undertaking in the pursuit of creating an environmentally sound Kapatagn community. Special thanks to Dr. Karen Belina F. De Leon, for allowing the authors to conduct this study; and to Mayor Benjie Y. Baguio and $\mathrm{Mr}$. Gilbert C. Eya for spearheading this undertaking.

\section{Literature Cited}

About Us Kapatagan. (2009). Philippines 2007 Brief Socio-Economic Profile. Kapatagan, Lanao del Norte Online. Retrieved from http://kapatagan.webs.com/ aboutus.htm

Anderson, N. P., Hart, J. M., Horneck, D. A., Sullivan, D. M., Christensen, N. W., \& Pirelli, G. J. (2010). Evaluating soil nutrients and $\mathrm{pH}$ by depth in situations of limited or no tillage in Western Oregon. Oregon State University, Extension Service. Retrieved from http://ir.library.oregonstate.edu/xmlui/bitstream/handle/1957/19024/e m9014.pdf

Arshad, M. A. \& Martin, S. (2002). Identifying critical limits for soil quality indicators in agro-ecosystems. Agriculture, Ecosystems and Environment, (88), 153-160. Retrieved from http://eusoils. jrc.ec.europa.eu/projects/scape/uploads/65/Arshad_Martin.pdf

Ball, J. (2001). Soil and Water Relationships. The Samuel Roberts Noble Foundation, Inc. Retrieved from http://www.noble.org ag/soils/soilwater relationships/

Beare, M. H., Cameron, K. C., Williams, P. H., \& Doscher, C. (1997). Soil quality monitoring for sustainable agriculture.Proc. 50th New Zealand Plant Protection Conf., (1997) 520-528. Retrieved from http://www. nzpps.org/ journal/50/nzpp_505200.pdf 
Costa, C. T., Strieder, M. L., Abel, S. \& Delatorre C. A. (2011). Phosphorus and nitrogen interaction: loss of QC identity in response to P or $\mathrm{N}$ limitation is anticipated in pdr23 mutant. Braz. J. Plant Physiol. (23)3.

Department of Environmental Protection. (2013). Watershed Management. Florida. Retrieved from http://www.dep.state.fl.us /water/watersheds/

Department of Horticulture. (2013). Cornell gardening resources Soil Basics. Cornell University. Retrieved from http://www.gardening. cornell.edu/factsheets/misc/soilbasics. html

Environmental Fact Sheet. (2006). Why watersheds are important to protect. New Hampshire Department of Environmental Services. (603), 271-3503. Retrieved from http://des.nh.gov/organization /commissioner/pip/factsheets/wmb/documents/wmb-19.pdf

Kenkel, J. (2003). Analytical Chemistry for Technicians. (3rd ed.). CRC Press LLC. USA. Pp. 445

Kostka, Z. (1994). Study of soil moisture spatial distribution in mountain catchment using GIS. EGIS Foundation. Retrieved from http://libraries. maine.edu/Spatial/gisweb/spatdb/ egis/eg94118.html

Kumasi, T. C., \& Asenso-Okyere, K. (2011). Responding to land degradation in the highlands of Tigray, Northern Ethiopia. International Food Policy Research Institute, Series 1142. Retrieved from http://www.ifpri.org/publication/responding-land-degradationhighlands-tigray-northern-ethiopia

Lannan, J. (2009). An evaluation of the South Australian evapotranspiration model using the FAO-56 guidelines. FAO-56 Evapotranspiration. Retrieved from http://www.productivewater services.com/images/SA-BoM-ETo-Evaluation-20-02-09-public.pdf 
Mandal, U. K., Ramachandran, K., Sharma, K.L., Satyam, B., Venkanna, K., UdayaBhanu, M., ... \& Masane, R. N. (2011). Assessing soil quality in a semiarid tropical watershed using a geographic information system. Soil Sci. Soc. Am. J. 75(3), 1144-1160. doi:10.2136/sssaj2009.0361

Manual, S. (2011). MMRDP (Mindanao Rural Development Program) to revive critical watersheds in Mindanao. The Philippine Star. Retrieved from http://www.philstar.com/agriculture/665236/mrdprevive-critical-watersheds-mindanao

Merrington, G. (2006). The development and use of soil quality indicators for assessing the role of soil in environmental interactions. Environment Agency, Rio House, Waterside Drive, Aztec West, Almondsbury, Bristol, BS32 4UD. Retrieved from http://cdn. environment-gency.gov.uk/scho0306 bkiq-e-e.pdf

Natural Resources. (2013). General Land and Water Characteristics and Resources Topography and Slope. Province of Lanao del Norte. Retrieved from http://www.lanaodelnorte.gov.ph/Profile/naturalresources.html

Natural Resources Conservation Service. (2013). Watershed programs and activities in New Jersey. United States Department of Ariculture. Retrieved from http://www.nrcs.usda.gov/wps/portal/nrcs/detail/nj /water/?cid=nrcs1 41p2_0 18964

Perry, L. (2003). pH for the Garden. Department of Plant and Soil Science, University of Vermont Extension. Retrieved from http://www.uvm.edu/pss/ppp/pubs/oh34.htm

Republic Act No. 7160. Local government code of the Philippines, devolving certain functions to LGU's, including the enforcement of laws on cleanliness and sanitation, and preparation of their respective solid waste management programs (1991). Retrieved from http://jagna.gov.ph/wp-content/uploads/2013/01/RA-7160.pdf 
Ritter, M. (2006). Soil texture triangle. The Physical Environment. Retrieved from http://www4.uwsp.edu/geo/faculty/ritter/glossary/s_u/ soil_texture_triangle.html

Roosebelt, F. D. (2011). Understanding soil acidity.Agricultural Bureau of South Australia. Retrieved from from http://www.agbureau.com.au /projects/soil_acidity/ABA_WS_soil_acidity_brochure_july_2011_v3 _lowres.pdf

Sahrawat, K. L., Wani, S. P., Pathak, P., \& Rego, T. J. (2010). Managing natural resources of watersheds in the semi-arid tropics for improved soil and water quality: A review. Agricultural Water Management. 97( 3), 375-381.

Self, J. R., \& Soltanpour, P. N. (2010). Soil sampling. Colorado State University Extension. Retrieved from http://www.ext.colostate.edu /pubs/ crops/00500.html

Siavoshi, M., Nasiri, A., \& Lawari, S. (2010). Effect of organic fertilizer on growth and yield components in rice (Oryza sativa L.). Journal of Agricultural Science, 3(3). doi:10.5539/jas.v3n3p217

Spriggs, G., \& Ray-Maitra, A. (2007). Particle-Size-Distribution of Nevada Test Site Soils. Lawrence Livermore National Laboratory. Retrieved from https://e-reports-ext.llnl.gov/pdf/352738.pdf

United Nations 'Rio+20' Earth Summit. (2012). The importance of natural capital. Natural Capital Declaration. Retrieved from http://www.naturalcapitaldeclaration.org/ the-declaration/

Wang, C., Zhao, C., Xu, Z., Wang, Y., \& Peng, H. (2013a). Effect of vegetation on soil water retention and storage in a semi-arid alpine forest catchment. Journal of Arid Land, 5 (2), 207-219. 
Wang, M, Zheng, Q, Shen, Q. \& Guo, S. (2013b). The Critical Role of Potassium in Plant Stress Response. International Journal of Molecular Sciences. Retrieved from http://www.ncbi.nlm.nih.gov /pmc/articles/PM C3645691/pdf/ijms-14-07370.pdf

Wintermyer, A. M. \& Kinter, E. B. (2004). Dispersing agents for particlesize analysis of soils. Transportation Research Board. Retrieved from http://trid.trb.org/view.aspx? id=121363

Wolflin, J. P., Russo, R. C., Burak, S., Karakaya, N., Orbi, A., Razinkovas, A., ... \& Torun, Y. (2008). Decision Making, Policy And Financing. Sustainable Use and Development of Watersheds NATO Science for Peace and Security. Series 2008, 513-527. Retrieved from http://link.springer.com/chapter/10.1007\% 2F978-1-4020-8558-1_31\# 